\title{
ДО ПИТАННЯ ВПРОВАДЖЕННЯ КРИМІНАЛЬНИХ ПРОСТУПКІВ
}

\section{АЛЕКСЕСВА-ДАНИЛЕНКО ЮЛія ВоЛодимирівН - аспіранТ Харківського національного університету внутрішніх справ}

DOI 10.32782/NP.2021.1.18

Стаття присвячена дослідженню впровадженню кримінального проступку в систему кримінального законодавства в Україні. Проаналізовано стан розроблення, законодавчого закріплення кримінального проступку та надано визначення поняття «дізнавач» та «кримінальний проступок». Здійснено аналіз теоретичних та законодавчих положень щодо визначення поняття «кримінальний проступок». Доведено, що в кожному конкретному випадку, визначаючи приналежність того чи іншого діяння до кримінального проступку,необхідно виходити $i_{3}$ комплексного аналізу обставин вчинення та суспільної небезпеки кримінального проступку. Впровадження норм щьодо кримінального проступку в межах Закону Украйни «Про внесення змін до деяких законодавчих актів Украӥни щодо спрощення досудового розслідування окремих категорій кримінальних правопорушенъ», на думку автора, є неправильним, оскільки характерною особливістю кримінального законодавства є його кодифiкація в єдиному правовому акті - Кримінальному кодексі України.

Ключові слова: кримінальний проступок, кримінальне правопорушення, злочин, кримінальна відповідальність, дізнавач, законодав-

Актуальність теми

Головним обов'язком держави $є$ захист життя людини, забезпечення ії прав і свобод. Провідна роль у виконанні цих обов'язків належить правоохоронним органам, оскільки їх безпосередня діяльність спрямована на захист життя, прав і свобод людини, попередження правопорушень, збереження правопорядку та інше. Саме від їх професіоналізму залежить правильна кваліфікація того чи іншого діяння, швидке реагування, віднесення кримінального правопорушення до «правильної» категорії та чітке розслідування. Так як на теперішній час органи слідства перевантажені кримінальними провадженнями та в силу необхідності упорядкувати правову кваліфікацію кримінальних проваджень 301 липня 2020 року в Україні введено поняття «кримінального проступку» та «дізнавача».

Стан наукової розробленості теми

Окремі кримінально-правові аспекти зазначеної проблематики в юридичній науці розглядали : В. І. Борисов, М. М. Дмитрук, Н. Ф. Кузнєцова, В. М. Куц, А. А. Музика, М. І. Панов, О.М. Аитвінов, В.Б. Харченко, А. А. Піонтковський, І. Ю. Романюк, В. Я. Тацій, Є. А. Стрельцов, М. І. Хавронюк, П. А. Фріс, М. Д. Шаргородський та інші, проте у зв'язку із змінами в кримінальному і кримінально-процесуальному законодавстві необхідно додаткове дослідження правової категорії кримінальних проступків.

Мета статті - проаналізувати особливості визначення кримінального проступку як кримінального правопорушення та повноваження дізнавача в кримінальних провадженнях стосовно кримінальних проступків. 


\begin{abstract}
Виклад основного матеріалу
Прагнення Української держави інтегруватись до європейської спільноти обумовлює проведення різного роду реформ, у тому числі правоохоронної системи та кримінального законодавства в цілому. Одним із таких нововведень 6 запровадження в Україні з 01 липня 2020 року понять «дізнавач» та «кримінальний проступок». Дане нововведення діє на підставі прийняття Закону України "Про внесення змін до деяких законодавчих актів України щодо спрощення досудового розслідування окремих категорій кримінальних правопорушень» від 22.11.2018 року [1]. Відповідно до статті 11 цього закону: «Кримінальним правопорушенням є передбачене цим Кодексом суспільно небезпечне винне діяння (дія або бездіяльність), вчинене суб'єктом кримінального правопорушення. Не є кримінальним правопорушенням дія або бездіяльність, яка хоча формально і містить ознаки будь-якого діяння, передбаченого цим Кодексом, але через малозначність не становить суспільної небезпеки, тобто не заподіяла і не могла заподіяти істотної шкоди фізичній чи юридичній особі, суспільству або державі [1].

Дізнавач - це службова особа підрозділу дізнання органу Національної поліції України або уповноважена особа іншого підрозділу поліції, яка уповноважена в межах компетенції, передбаченої КПК України, здійснювати досудове розслідування кримінальних проступків [2].
\end{abstract}

Наявність інституту кримінального проступку не $\epsilon$ новим у праві, оскільки ще за часів середньовіччя, зокрема, законодавстві Англії існував поділ злочинів на фелонію (вона охоплювала злочини 3 високим ступенем суспільної небезпеки, за які передбачалося покарання у вигляді смертної кари та конфіскації майна) і місдімінор (до нього належали менш небезпечні злочини, які посягали на інтереси приватних осіб, що не посягали на інтереси корони та за які не передбачалася смертна кара і конфіскація майна) [3].

Подібна класифікація суспільно небезпечних діянь була закріплена і в Криміналь- ному кодексі (КК) Франції 1810 р., згідно 3 якою суспільно небезпечні діяння, що мали тяжкі та «ганебні» покарання, вважалися злочинами; діяння, за які було встановлено так звані виправні покарання - проступками; а правопорушення, за які передбачалися поліцейські покарання, називалися поліцейськими правопорушеннями. У КК Франції 1992 р. така класифікація з деякими уточненнями збережена [4].

Сьогодні в кримінальному законодавстві багатьох країн (Польщі, Франції, Італії, ФРН, США, Угорщині та ін.) розрізняють злочин і кримінальний проступок. В Україні реформування кримінального та адміністративного законодавства започаткувала Концепція реформування кримінальної юстиції України, затверджена Указом Президента України від 8 квітня 2008 р. № 311/2008 [5] та «фінішувала» вище згаданим Законом України «Про внесення змін до деяких законодавчих актів України щодо спрощення досудового розслідування окремих категорій кримінальних правопорушень» від 22.11.2018 року [1]

Відтепер кримінальні правопорушення поділяються на кримінальні проступки і злочини. 3 Кримінального кодексу України зникає поняття «злочин середньої тяжкості», а всі злочини, які раніше так класифікувалися, вважатимуться нетяжкими. Кримінальним проступком 6 передбачене цим Кодексом діяння (дія чи бездіяльність), за вчинення якого передбачене основне покарання у вигляді штрафу в розмірі не більше трьох тисяч неоподатковуваних мінімумів доходів громадян (до 51 тис. грн) або інше покарання, не пов'язане 3 позбавленням волі.

Згідно з Кримінальним кодексом України, кримінальні злочини поділяються на:

- нетяжкі (основне покарання у вигляді штрафу в розмірі не більше ніж десять тисяч неоподатковуваних мінімумів доходів громадян (170 тис. грн) або позбавлення волі на строк не більше ніж 5 років);

- тяжкі (основне покарання у вигляді штрафу в розмірі не більше ніж двадцять п'ять тисяч неоподатковуваних мінімумів доходів громадян (340 тис. грн) або позбавлення волі на строк не більше ніж 10 років); 


\section{Кримінальне право, кримінальний процес та криміналістика}

- особливо тяжкі (основне покарання у вигляді штрафу в розмірі понад двадцять п'ять тисяч неоподатковуваних мінімумів доходів громадян (425 тис. грн), позбавлення волі на строк понад десять років або довічного позбавлення волі).

У зв'язку із змінами в Кримінальному кодексі України особа, яка вперше вчинила кримінальний проступок або необережний нетяжкий злочин (а було - «вперше вчинила злочин невеликої тяжкості або необережний злочин середньої тяжкості»), крім корупційних кримінальних правопорушень, звільняеться від кримінальної відповідальності, якщо вона після вчинення кримінального правопорушення (а було - «злочину») щиро покаялася, активно сприяла розкриттю кримінального правопорушення і повністю відшкодувала завдані нею збитки або усунула заподіяну шкоду [6].

Щодо кримінальних проступків діє глава 25 Кримінального процесуального кодексу України «Особливості досудового розслідування кримінальних проступків».

Кримінологічні проступки, передбачені в 98 статтях Кримінального кодексу України, як приклад, серед них можна назвати наступні:

- умисне легке тілесне ушкодження (ч.1, 2 ст.125 КК України);

- побої та мордування (тільки ч.1 ст.126 КК України);

- погроза вбивством (тільки ч. 1 ст.129 КК України);

- розголошення відомостей про проведення медичного огляду на виявлення зараження вірусом імунодефіциту людини чи іншої невиліковної інфекційної хвороби (ст.132 КК України);

- примушування до стерилізації без добровільної згоди потерпілої особи (ч.4 ст. 134 КК України);

- ненадання допомоги хворому медичним працівником (тільки ч.1 ст.139 КК України);

- примушування до вступу в статевий зв'язок (тільки ч. 1, 2 ст.154 КК України);

- порушення таємниці голосування (тільки ч.1 ст.159 КК України);

- підкуп виборця, учасника референдуму (тільки ч.1 ст.160 КК України);
- порушення недоторканості житла (тільки ч.1 ст.162 КК України);

- ухилення від сплати аліментів на утримання дітей (ст.164 КК України);

- ухилення від сплати коштів на утримання непрацездатних батьків (ст.165 КК України);

- розголошення таємниці усиновлення (удочеріння) (тільки ч.1 ст.168 КК України);

- грубе порушення законодавства про працю (тільки ч.1 ст.172 КК України);

- грубе порушення угоди про працю (ст.173 КК України);

- невиплата заробітної плати, стипендії, пенсії чи інших установлених законом виплат (ст.175 КК України);

- порушення права на безоплатну медичну допомогу (ст.184 КК України);

- крадіжка (тільки ч. 1 ст. 185 КК України);

- шахрайство (тільки ч.1 ст.190 КК України);

- незаконне привласнення особою знайденого або чужого майна, що випадково опинилося у неї (ст.193 КК України);

- погроза знищення майна (ст.195 КК України);

- розголошення комерційної або банківської таємниці (ст.232 КК України);

- незаконне заволодіння грунтовим покривом (поверхневим шаром) земель (тільки ч. 1 ст.239-1 КК України);

- незаконне заволодіння землями водного фонду в особливо великих розмірах (тільки ч.1 ст.239-2 КК України);

- порушення законодавства про континентальний шельф України (тільки ч.2 ст.244 КК України);

- порушення законодавства про захист рослин (ст.247 КК України);

- незаконне полювання (тільки ч. 1 ст.248 КК України);

- незаконне зайняття рибним, звіриним або іншим водним добувним промислом (тільки ч.1 ст.249 КК України);

- умисне знищення або пошкодження територій, взятих під охорону держави, та об'єктів природно-заповідного фонду (тільки ч. 1 ст.252 КК України);

- проєктування чи експлуатація споруд без систем захисту довкілля (тільки ч.1 ст.252 КК України); 
- безгосподарське використання земель (тільки ч.1 ст.254 КК України);

- умисне невиконання угоди про примирення або про визнання винуватості (ст.3891 КК України);

- невиконання обмежувальних заходів, обмежувальних приписів або непроходження програми для кривдників (ст.390-1 КК України);

- порушення правил адміністративного нагляду (ст.395 КК України);

- втручання в діяльність захисника чи представника особи (ст.397 КК України);

- представництво в суді без повноважень (ст.400-1 КК України);

- необережне знищення або пошкодження військового майна (тільки ч.1 ст.412 КК України) та інші.

До кримінальних законодавець відносить визначені Кримінальним кодексом діяння (дію чи бездіяльність), за вчинення яких передбачає основне покарання у вигляді штрафу в розмірі не більш ніж 3000 неоподаткованих мінімумів доходів громадян (51 тис. грн.) або інші покарання, не пов'язані з позбавленням волі.

Кримінальні проступки будуть розслідуватись за спрощеною процедурою, хоча багато хто з них (як, наприклад, погроза вбивством, «рейдерські» статті та інші) є досить серйозними й небезпечними правопорушеннями для суспільства. Більшості 3 них не торкнулося й підвищення штрафів. Тобто суми покарань за них будуть усе ще мізерними. Отже, правопорушники, що вчинили кримінальні проступки, відчуватимуть себе набагато спокійніше, ніж до набрання змінами чинності [6]. Слід також зазначити, що процедура дізнання передбачає ширший перелік слідчих (розшукових) дій, які можуть вчинятися до внесення відомостей до Єдиного реєстру досудових розслідувань, порівняно із процедурою загального досудового слідства.

Зокрема, дізнавач може:

- відбирати пояснення;

-

- отримувати висновки спеціалістів;

- знімати показання технічних приладів та технічних засобів, що мають функції фото- і кінозйомки, відеозапису, чи засобів фото- і кінозйомки, відеозапису;

- вилучати знаряддя i засоби вчинення кримінального проступку, речі і документи, які $\varepsilon$ безпосереднім предметом кримінального проступку або які виявлені під час затримання особи, особистого огляду або огляду речей.

Строки розслідування кримінальних проступків: 3 дня повідомлення особі про підозру досудове розслідування повинно бути закінчене впродовж 72 годин або 20 діб, якщо підозрюваний не визнає вину або існує необхідність проведення додаткових слідчих (розшукових) дій або вчинення кримінального проступку неповнолітнім [7].

\section{Висновки}

Інститут кримінальних проступків має бути, але його ознаки необхідно чітко розмежовувати 3 кримінальним злочином. На думку автора, під кримінальним проступком потрібно розуміти проміжний вид діяння між злочином і адміністративним правопорушенням, але впровадження норм щодо кримінального проступку в межах Закону України « Про внесення змін до деяких законодавчих актів України щодо спрощення досудового розслідування окремих категорій кримінальних правопорушень» від 22.11.2018 року є неправильним, оскільки характерною особливістю кримінального законодавства є закріплення його норм саме в Кримінальному кодексі України, тому доцільно було 6 розробити та впровадити Кодекс про кримінальні проступки, де під кримінальним проступком розуміти протиправну, винну (умисну або необережну ) дію чи бездіяльність особи, яка посягає на громадський порядок, власність, права і свободи громадян, установлений законом порядок, за яку законом передбачено відповідальність, не позбавлену з позбавленням волі.

\section{Література}

1. Про внесення змін до деяких законодавчих актів України щодо спрощення досудового розслідування окремих категорій кримінальних правопорушень: Закон України від 22 листопада 2018 року // Відомості Верховної Ради України. - 2018. [Електро- 


\section{Кримінальне право, кримінальний процес та криміналістика}

нний ресурс]: https://zakon.rada.gov.ua/laws/ card/2617-19

2. Наказ МВС України № 405 від 20.05.2020 року «Про затвердження Положення про організацію діяльності підрозділів дізнання органів Національної поліції України». [Електронний ресурс]: https:// zakon.rada.gov.ua/laws/show/z0491-20\#Text

3. Федотова Г. В. Правові тенденції визначення кримінального проступку в кримінальному законодавстві / Г.В.Федотова, А. О. Расюк [Електронний ресурс]. - Режим доступу : http://ivpz.org/golovnakonferents

4. Стрельцов Є. А. Проблеми класифікації суспільно небезпечних діянь (зміст та напрямки) / С. $\Lambda$. Стрельцов [Електронний ресурс]. - Режим доступу : http:// ivpz.org/golovna-konferents.

5. Концепція реформування кримінальної юстиції України [Електронний ресурс]. - Режим доступу : http:/zakon1.rada.gov.ua/ cgibin/laws/main.cgi?nreg $=311 \% 2$ F2008\&my i d $=4$ / U M f P E G z n h h S T H . Z i 2 E W z A. HdlPosFggkRbIlc.

6. 112 UA.Новини «Почалася нова ера кримінальних проступків». [Електронний ресурс]: https:/ua.112.ua/mnenie/pochalasianova-era-kryminalnykh-prostupkiv-541382. html

7. Юридичний портал Протокол-Новини-Кримінальний проступок. Як 31
The article is devoted to the study of the introduction of criminal misconduct in the system of criminal law in Ukraine. The state of development, legislative consolidation of a criminal offense is analyzed and the definition of the concept of "cognizant" and "criminal offense" is given. The analysis of theoretical and legislative provisions concerning the definition of the concept of "criminal offense" is carried out. It is proved that in each case, determining the affiliation of an act to a criminal offense, it is necessary to proceed from a comprehensive analysis of the circumstances of the commission and the public danger of a criminal offense. According to the author, the introduction of norms on criminal misconduct within the Law of Ukraine "On Amendments to Certain Legislative Acts of Ukraine to Simplify Pre-trial Investigation of Certain Categories of Criminal Offenses" is incorrect, as a characteristic feature of criminal law is its codification in a single legal act - the Criminal Code of Ukraine.

Key words: criminal offense, criminal offense, crime, criminal liability, coroner, legislation.

липня зміняться строки і процес розгляду справ у судах. [Електронний ресурс]: https://protocol.ua/ru/kriminalniy_prostupok_ yak_z_1_lipnya_zminyatsya_stroki_i_protses_ rozglyadu_sprav_u_sudah/ .

8. Кримінальний процесуальний кодекс України. [Електронний ресурс]: https:// zakon.rada.gov.ua/laws/show/4651-17\#Text 